\title{
DERMATOGLYPHIC PATTERNS IN MENTALLY RETARDED CHILDREN
}

\author{
Romi Sadanandan'1, Ushadevi K. B2
}

${ }_{1}^{1}$ Additional Professor, Department of Anatomy, Government Medical College, Trivandrum, Kerala.

${ }^{2}$ Additional Professor, Department of Anatomy, Government Medical College, Trivandrum, Kerala.

ABSTRACT

\section{BACKGROUND}

Mental retardation is a common problem. Almost 3\% of the population have an intelligence quotient below 70.

The present study has been undertaken to find out whether there was any definite dermatoglyphic pattern suggestive or diagnostic of idiopathic mental retardation.

\section{MATERIALS AND METHOD}

It includes analysis of 100 children with mental retardation and 120 school going children having average intelligence and behaviour. Palmar and finger ridges were taken by Cummins and Midlo ink method. Qualitative and quantitative analysis were done.

100 children with idiopathic mental retardation were selected from the following institutions-

1. Government institutions for mentally retarded children at Pangappara, Trivandrum.

2. Neurology clinic at S.A.T. Hospital, Trivandrum.

3. Maryon School at Kanaka Nagar, Trivandrum.

Controls were selected from the nearby Government schools.

DESIGN- Descriptive study.

\section{RESULTS}

Higher frequency of ulnar loop and arches, lower frequency of whorls were found in mentally retarded male children but lower frequency of ulnar loops and higher frequency of arches and whorls were found in mentally retarded female children. Higher values of total finger ridge count (TFRC), atd angle, and a-b ridge count in both sexes.

\section{CONCLUSION}

Idiopathic mental retardation has a strong genetic basis.

\section{KEYWORDS}

Dermatoglyphics, Mental Retardation, Total Finger Ridge Count (TFRC), Atd Angle and a-b Ridge Count.

HOW TO CITE THIS ARTICLE: Sadanandan R, Ushadevi KB. Dermatoglyphic patterns in mentally retarded children. J. Evolution Med. Dent. Sci. 2016;5(83):6161-6165, DOI: 10.14260/jemds/2016/1393

\section{BACKGROUND}

Dermatoglyphics is the scientific study of epidermal ridges and their configuration on palmar and plantar region. The dermal ridges are formed during the $3^{\text {rd }}$ month of intrauterine life and completed by $7^{\text {th }}$ month. The fingerprint patterns are genetically determined and once formed doesn't alter after birth or with environment changes. ${ }^{1}$

Mental retardation is also known as intellectual disability. It is characterised by below average intellectual functioning level and the significant limitation in daily living skills.2. The present study was undertaken to evaluate the dermatoglyphic features and to note any specific variations or diagnostic features in mentally retarded children.

Financial or Other, Competing Interest: None.

Submission 10-09-2016, Peer Review 04-10-2016,

Acceptance 11-10-2016, Published 14-10-2016.

Corresponding Author:

Romi Sadanandan,

The Memphis, 1A, Regency Manor,

Ambala Nagar, Kowdiar P. O.,

Trivandrum-695003,

Kerala, India.

E-mail:drromisuresh@yahoo.com

DOI: $10.14260 /$ jemds/2016/1393
Human fingerprints are unique and they offer a means of personal identification.3,4 Fingerprint patterns are of multifactorial polygenic inheritance. In this study, dermatoglyphic patterns of mentally retarded children are compared with the controls.

\section{MATERIALS AND METHODS}

The study was done among 100 children with idiopathic mental retardation from below institutions for mentally retarded children.

1. Government Institutions for mentally retarded children at Pangappara, Trivandrum.

2. Neurology Clinic at S. A. T. Hospital, Trivandrum.

3. Maryon School at Kanaka Nagar, Trivandrum.

120 school going children who did not exhibit any mental deficiency formed the control group. These children were selected from nearby Government schools of age group 7-15 years of both sexes.

\section{Inclusion Criteria}

Children between the age group 7-15 years. Mentally retarded children not affected by Down syndrome.

\section{Exclusion Criteria}

Children with hand deformity. Children below 7 years and above 15 years. The palmar prints of subjects and controls 
were taken on white paper by Ink method as described by Cummins and Midlo.5 Printer's ink, roller (Fig.1), glass inking slab, a cylinder and good quality paper were used.

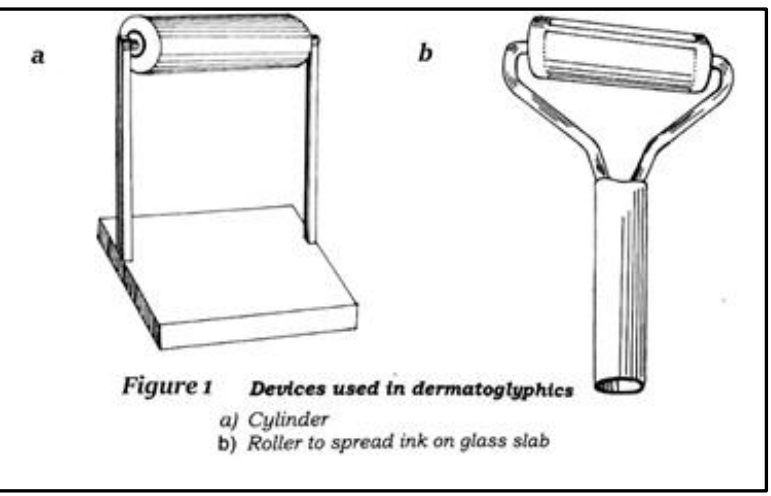

Children were directed to wash their hands with soap \& water and dried. A small amount of printer's ink was applied on the glass slab and was spread in to a thin even film with a roller. Hand was pressed firmly against the slab. After ensuring that the ink was uniformly spread on the palms, palmar impressions were recorded from the level of distal crease of the wrist to the fingertips. For better printing of the hollow of the palm it was rolled over a paper covered cylinder. Individual fingertip patterns were recorded separately and following analyses were done.

\section{Qualitative Analysis}

Type of pattern of finger tips - loops, arches and whorls.

\section{Quantitative Analysis}

Total finger ridge count (TFRC), atd angle, a-b ridge count.

\section{Type of Pattern of Finger Tips}

Using a magnifying hand lens, the patterns were studied. Type of patterns in left hand were charted beginning from little finger to thumb, while in right hand from thumb to little finger. Radial loop, ulnar loop, arches and whorls were recorded (Fig. 2)

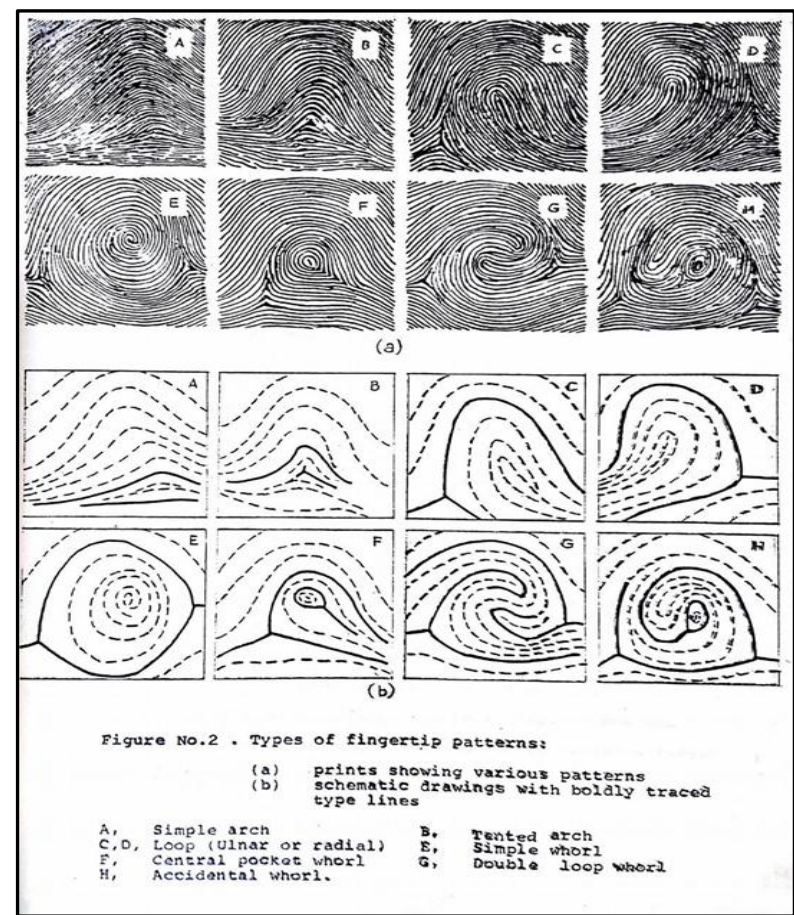

Total Finger Ridge Count (TFRC)

Finger ridge counting was done by a straight line connecting the tri-radial point to the point of core. Total finger ridge count is the sum of ridge count of all 10 fingers. (Fig. 3).

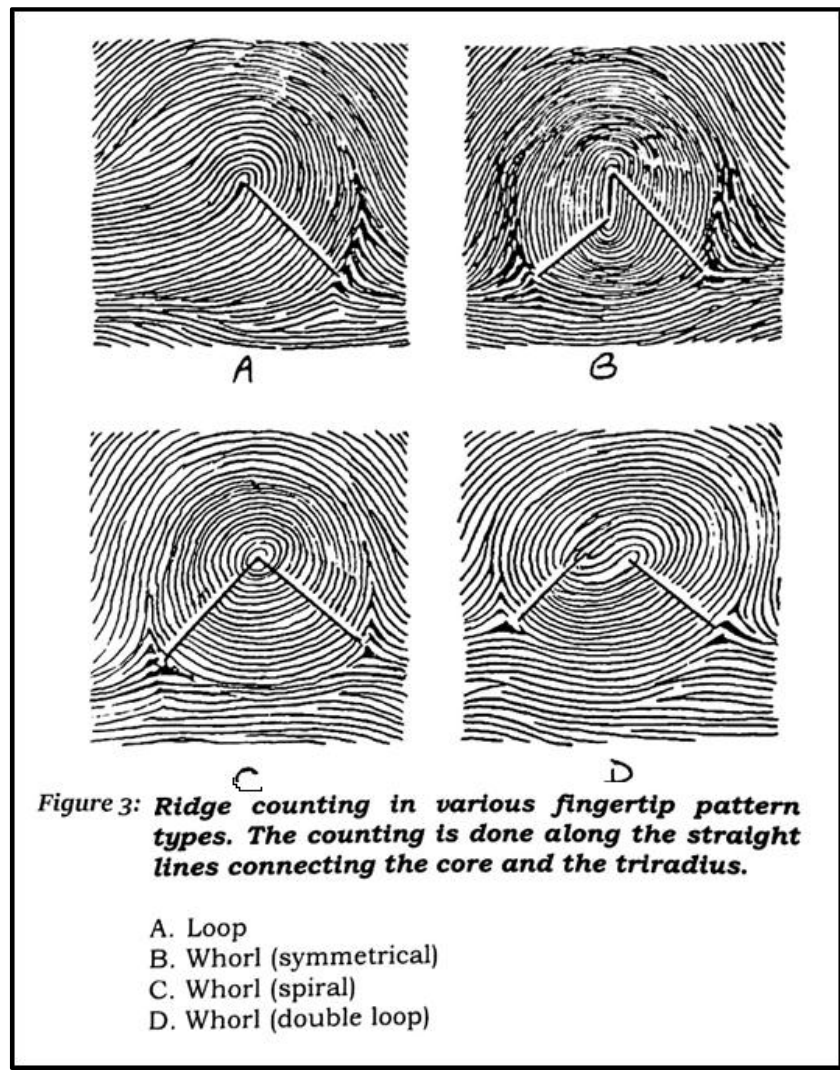

\section{Atd Angle}

It was measured from lines drawn from the digital tri-radius 'a ' to the axial tri-radius ' $t$ ' and from this to the digital tri-radius 'd' and values were taken using a protractor (Fig. 4)

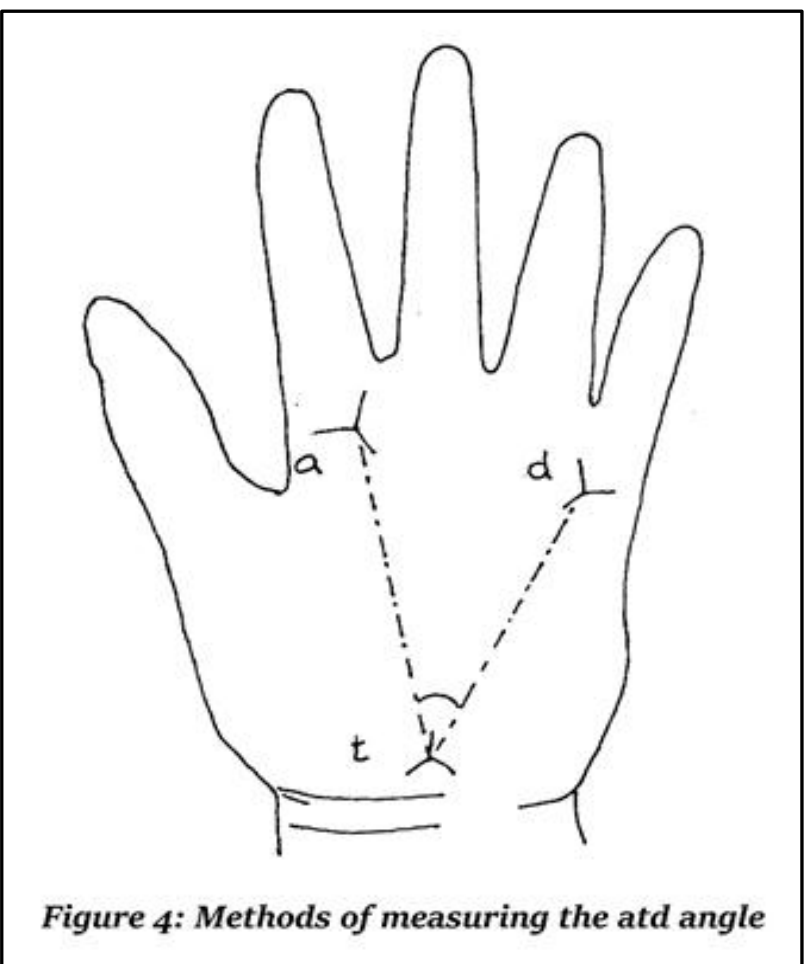




\section{a -b Ridge Count}

A straight line connecting the digital tri-radii 'a' and 'b' drawn and the ridges were counted (Fig. 5)

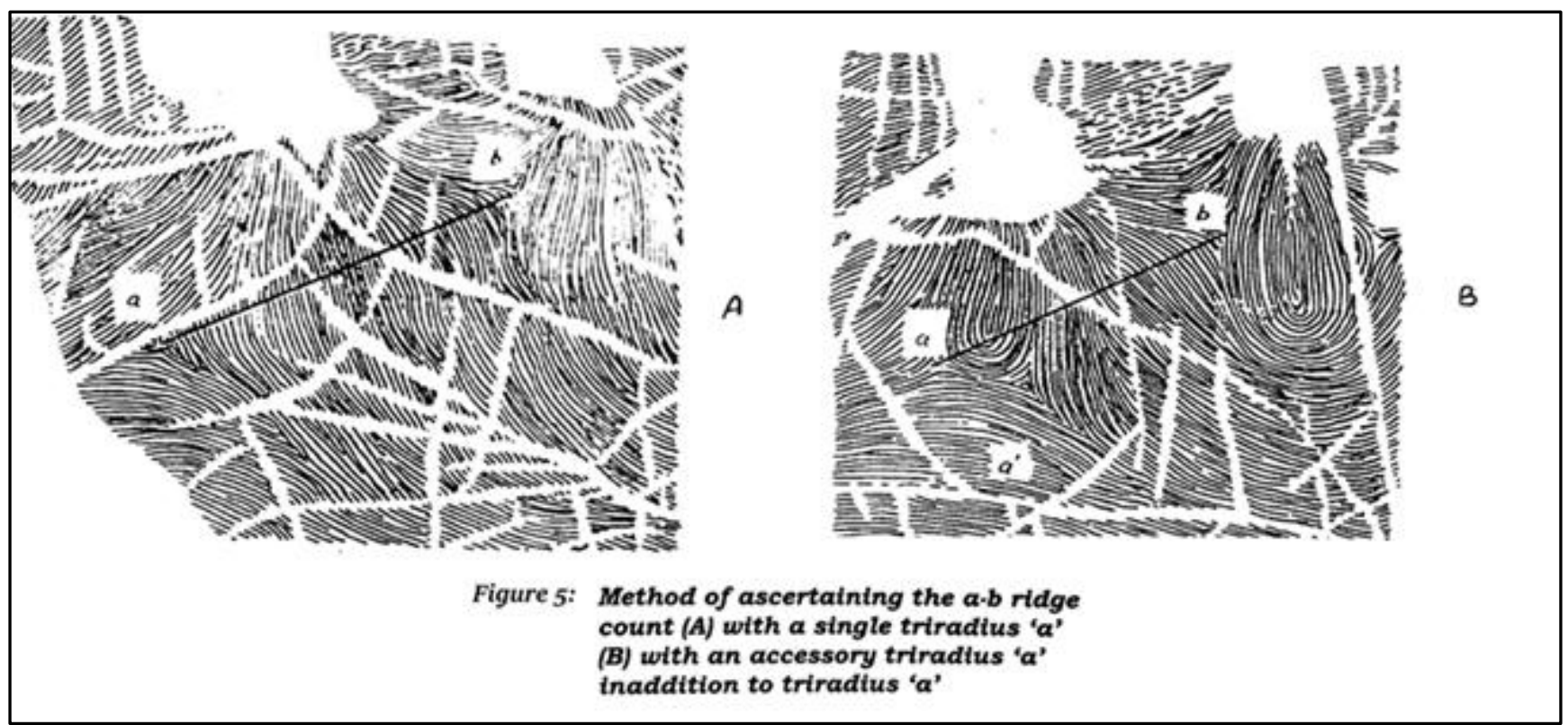

\section{Statistical Analysis}

The dermatoglyphic patterns on right and left hands were analysed sex-wise and using mean and standard deviations the statistical significance was assessed.

\section{RESULTS}

\begin{tabular}{|c|c|c|c|c|c|c|c|c|c|c|c|c|c|}
\hline \multicolumn{14}{|c|}{ Mean Percentage of Fingertip Patterns of Control and Mentally Retarded Children } \\
\hline & \multicolumn{7}{|c|}{ Left } & \multicolumn{6}{|c|}{ Right } \\
\hline \multicolumn{14}{|c|}{ Digit } \\
\hline Pattern type & & & I & II & III & IV & $\mathbf{V}$ & $\mathbf{V}$ & IV & III & II & I & All digits \\
\hline \multirow{4}{*}{ Ulnar Loop } & Male & $\mathrm{C}$ & 75 & 45 & 60 & 60 & 65 & 65 & 55 & 80 & 40 & 80 & 63 \\
\hline & & MR & 92 & 54 & 63 & 55 & 83 & 79 & 50 & 71 & 71 & 79 & 70 \\
\hline & Female & $\mathrm{C}$ & 80 & 50 & 60 & 45 & 65 & 65 & 60 & 70 & 60 & 80 & 64 \\
\hline & & MR & 83 & 44 & 55 & 39 & 78 & 67 & 44 & 72 & 61 & 78 & 62 \\
\hline \multirow{4}{*}{ Radial Loop } & Male & $\mathrm{C}$ & 0 & 0 & 0 & 0 & 0 & 0 & 5 & 0 & 0 & 0 & 5 \\
\hline & & MR & 0 & 0 & 8 & 0 & 0 & 0 & 0 & 0 & 0 & 0 & 8 \\
\hline & Female & $\mathrm{C}$ & 0 & 0 & 5 & 15 & 0 & 0 & 5 & 5 & 0 & 0 & 8 \\
\hline & & MR & 0 & 0 & 6 & 11 & 0 & 0 & 0 & 6 & 0 & 0 & 8 \\
\hline \multirow{4}{*}{ Arches } & Male & $\mathrm{C}$ & 0 & 0 & 5 & 5 & 0 & 0 & 10 & 0 & 0 & 0 & 7 \\
\hline & & MR & 0 & 0 & 17 & 17 & 5 & 5 & 25 & 8 & 0 & 5 & 12 \\
\hline & Female & $\mathrm{C}$ & 5 & 0 & 15 & 5 & 0 & 0 & 10 & 10 & 0 & 5 & 8 \\
\hline & & MR & 0 & 0 & 6 & 11 & 0 & 0 & 11 & 0 & 0 & 0 & 9 \\
\hline \multirow{4}{*}{ Whorls } & Male & $\mathrm{C}$ & 25 & 55 & 35 & 35 & 35 & 35 & 30 & 20 & 60 & 20 & 35 \\
\hline & & MR & 8 & 46 & 21 & 29 & 13 & 17 & 33 & 21 & 29 & 17 & 23 \\
\hline & Female & $\mathrm{C}$ & 15 & 50 & 20 & 35 & 35 & 35 & 25 & 15 & 40 & 15 & 29 \\
\hline & & MR & 17 & 56 & 33 & 39 & 22 & 33 & 44 & 22 & 39 & 22 & 33 \\
\hline \multicolumn{14}{|c|}{$\begin{array}{l}\text { Table 1: Shows ulnar loops were higher in MR male children in all digits taken together, except in digit IV on both hands } \\
\text { III and I in right hand. Female children showed lower frequency of ulnar loops except in digit V of both hands, digit I in lef } \\
\text { and III, II in right hand. Arch patterns were higher than whorls in males, but whorls were higher in females. Radial loops } \\
\text { were comparatively low. } \\
\text { C-Control children MR-mentally retarded children. }\end{array}$} \\
\hline
\end{tabular}




\begin{tabular}{|c|c|c|c|c|}
\hline \multicolumn{5}{|c|}{ Mean of Total Ridge (TFRC)of all Digits } \\
\hline \multicolumn{3}{|c|}{ Male } & \multicolumn{2}{|c|}{ Female } \\
\hline & Left & Right & Left & Right \\
\hline Mean C & 56.92 & 58.44 & 55.78 & 56.17 \\
\hline S.D & $(+)-6.9$ & $(+)-5.75$ & $(+)-16.33$ & $(+)-15.55$ \\
\hline Mean MR & 42.95 & 43 & 40.42 & 40.08 \\
\hline S.D & $(+)-13.02$ & $(+)-11.75$ & $(+)-10.66$ & $(+)-10.22$ \\
\hline
\end{tabular}

\begin{tabular}{|c|c|c|c|c|}
\hline \multicolumn{5}{|c|}{ Mean atd angle } \\
\hline \multicolumn{3}{|c|}{ Male } & \multicolumn{2}{|c|}{ Female } \\
\hline & Left & Right & Left & Right \\
\hline Mean C & 38.1 & 39 & 39.7 & 40.9 \\
\hline S.D & $(+)-3.46$ & $(+)-3.42$ & $(+)-4.49$ & $(+)-3.95$ \\
\hline Mean MR & 42.95 & 43 & 40.42 & 40.08 \\
\hline S.D & $(+)-8.97$ & $(+)-9.21$ & $(+)-4.25$ & $(+)-3.29$ \\
\hline \multicolumn{5}{|c|}{ Table 3: Shows higher atd angle in both sexes but more in male } \\
\hline
\end{tabular}

\begin{tabular}{|c|c|c|c|c|}
\hline \multirow{2}{*}{} & \multicolumn{4}{|c|}{ Mean a-b Ridge Count } \\
\cline { 2 - 5 } & Left & Right & Fefle & Right \\
\cline { 2 - 5 } Mean C & 24.08 & 24.08 & 24.39 & 24.72 \\
\hline S.D & $(+)-4.34$ & $(+)-4.25$ & $(+)-4.12$ & $(+)-4.13$ \\
\hline Mean MR & 33.76 & 33.47 & 26.1 & 25.7 \\
\hline S.D & (+)-7.29 & $(+)-6.76$ & $(+)-4.38$ & $(+)-5.33$ \\
\hline \multicolumn{4}{r}{} \\
\hline
\end{tabular}

\section{DISCUSSION}

Mental subnormality is one of those disorders where the understanding or the therapy is a matter of disillusionment. Dermatoglyphic patterns have been utilised as a diagnostic tool in disorders which could be either gross chromosomal or localised genetic. Fingerprint patterns are easily deposited on suitable surfaces by sweat secretions from eccrine glands present in the friction ridges of fingertips. ${ }^{6}$

In this study, a higher frequency of ulnar loop and arch patterns in male children and a lower frequency of whorls were observed. Higher ulnar loop was also reported by Reddi et $\mathrm{al}^{7}$ and Bhagwat $\mathrm{VB}^{8}$ while the reverse was observed by Alter and Bruhl, 9 Saxena and Mathur,10 Chakrabarthi and Magotra ${ }^{11}$ and Purendare et al. ${ }^{12}$

The percentage frequency of whorls in mentally retarded male children was lower than that of control, similar to the findings of Reddi, ${ }^{7}$ but mentally retarded female children showed higher frequency of whorls, which agrees with the findings of Saxena and Mathur. ${ }^{10}$ Higher arch pattern in this study was also observed by Purandare. ${ }^{12}$ It was also noticed that the radial loop pattern shows least frequency in the present study.

Total finger ridge count was found to be higher in mentally retarded children of both sexes but more in left hand of male children. TFRC has a well-documented polygenic or multifactorial inheritance ${ }^{13,14}$
A statistically significant increase in mean atd angle in mentally retarded children of both sexes was found in this study. Similar finding was reported by Kher, ${ }^{15}$ and Simsek. ${ }^{16}$ A-b ridge count is higher in mentally retarded children of both sexes. Present study agrees with the results reported by Fang. ${ }^{17}$

\section{Relevance}

As the study of dermatoglyphic pattern is non-invasive and incurs very little expense, this method can be used as a diagnostic tool for mental retardation among the low achievers in schools. This will help in creating awareness in the parents of such children. Moreover, an early diagnosis will help in framing the rehabilitation programs. The suggestive cases could be subjected to mere advanced, expensive and sophisticated methods such as cytogenetic analysis and polymerase chain reaction.

\section{REFERENCES}

1. van Karnebeek CDM. Aetiology of mental retardation or borderline cognitive delay in 281 children referred to a tertiary care centre: a prospective study. In: van Kamebeek CDM edr. Mental retardation. University of Amsterdam: 2002:75-108.

2. Sharma MK, Jhawar P, Sharma H, et al. Dermatoglyphics an attempt to predict downs syndrome. Int J Biol Med Res 2012;3(2):1631-35. 
3. Rastogi P, Pillai KR. A study of fingerprints in relation to gender and blood group. J Indian Acad Forensic Med 2010;32(1):11-14.

4. Bhavana D, Ruchi J, Prakash T, et al. Study of fingerprint patterns in relationship with blood group and gender-a statistical review. Res J Forensic Sci 2013;1(1):15-17.

5. Cummins H, Midlo C. Palmar and plantar epidermal ridge configurations (dermatoglyphics) in EuropeanAmericans. AM J Phy Anthropology 1926;9(4):471-502.

6. Pillai VV. Text book of forensic medicine and toxicology. $15^{\text {th }}$ edn. Hyderabad: Paras Medical Publishers 2009:5394.

7. Reddi YR, Rao SV, Kumari KC. Dermatoglyphics in mental retardation. Indian Paediatrics 1976;13(8):629-33.

8. Bhagwat VB, Meshram MM. Study of palmar dermatoglyphics in mentally retarded children. IOSRJDMS 2013;8(1):23-7.

9. Alter M, Bruhl HH. Dermatoglyphics in idiopathic Mental Retardation. Amer J Dis Child 1967;113(6):702-6.
10. Saxena PN, Mathur PP. Evaluation of Dermatoglyphics in mental deficiency. Indian J Paediatrics 1972;9(10):627-8.

11. Chakraborti NC, Magotra ML. Dermatoglyphics in clinical paediatrics. Indian Paediatrics 1976;13(5):355-8.

12. Purandare H, Atre PT, Vare AM. Dermatoglyphic features in mentally retarded children. J Anat Soc India 1978;27(3):127-33.

13. Holt SB. Genetics of dermal ridge. Springfield 111: Charles C Thomas Publishers 1968; P. 400.

14. Thompson JS, Thomson MW. Dermatoglyphics in medical genetics. Indian Paed 1979;16(2):108-15

15. Kher, Indurkar MB. Dermatoglyphics in paediatric practice. Indian Journal of Medical Science 1971;25:618.

16. Simsek S, Taskiran H, Karakaya N, et al. Dermatoglyphic analysis in children with cerebral palsy. Neurobiology (Bp) 1998;6(3):373-80.

17. Fang TC. A note on the a-b ridge count and intelligence. J Ment Science 1952;98(410):185-6. 